\title{
Selection of Bali Cattle as a Bull in Nusa Penida Island-Bali Based on Its Performance and Breeding Value
}

\author{
Dewi Ayu Warmadewi*, I N Ardika and Putra, IGAA
}

\author{
Faculty of Animal Husbandry, Udayana University, Jalan PB Sudirman, \\ Jalan PB Sudirman, Denpasar-Bali \\ *Corresponding Author: dewiayuwarmadewi@unud.ac.id
}

\begin{abstract}
Selection program applied to improve the animal genetic potential. This program can be carried out based on the performance and breeding values of the economic trait of each individual. The research was carried out for 5 month (from May until September 2018). The purpose of this study was to find out the superior Bali bull by determining of chest girth male Bali cattle. This study used purposive random sampling method. The number of male Bali cattle with incisor of I0,I1,I2 used in this study were 147,29,19 heads respectively. Performance test was calculated by formula of $\mathrm{BV}=\mathrm{h}^{2}(\mathrm{Pi}-\mathrm{P})$ (Hardjosubroto, 1994). The results showed that the average of chest girth male Bali Cattle for I0, I1 and I2 were $135,65 \pm 16,98 \mathrm{~cm} ; 159,57 \pm 13,75 \mathrm{~cm}$ and $166,26 \pm 19,94 \mathrm{~cm}$ respectively. Based on the breeding value, male Bali cattle coded BK030 with I1 and BK101 with I2 were recommended as a superior Bali bulls because of their highest ranking.
\end{abstract}

Key words: Bali cattle, chest girth, breeding value

\section{INTRODUCTION}

Bali cattle is one of Indonesia's germplasm that has to be kept its purity, especially for breeding purpose to get a superior breed that fits for its agroecosystem [1].

But recently, Bali cattles are assumed that their genetic potential decline which can be seen from the decrease in body weight. Efforts to improve the genetic quality of Bali cattle can be done through breeding actions by implementing a selection and breeding program. In addition, this program can be used as an effort to conserve and develop livestock populations. The selection program can be carried out based on the performance and breeding values of the economic trait of each individual.

In the field, the measurement of the trait that has an economic value is enough to be carried out in one character only if it has a close relationship with other traits.
Research conducted by Tama, et al. states that chest girth has a closer relationship with body weight compared to body length and shoulder height [2]. This statement is supported by Warmadewi, et al. who obtained that effective selection was carried out on the chest girth [3]. Warmadewi, et al. stated that a higher selection response was obtained in the measurement of chest girth compared to body length and shoulder height [4].

Breeding values cannot be measured directly, it means that an individual can not be seen from its genes but it can be predicted or estimated based on its productivity. Breeding value of an animal shows the superiority of its genetic potential compare to the average population. Johansson and Rendell stated that livestock that have greater breeding value would be better to be used as substitute livestock compared to cattle that have lower breeding values [5]. Furthermore, the selected livestock are 
those that have high breeding values. In addition, it depends on how much livestock will be needed as replacement animals. Today the selection program can be used to get the prospective superior male to be used to support the government program, namely the UPSUS SIWAB program.

The study was conducted on Nusa Penida Island because the government has determined this island as a source of Bali cattle breeding stock in Bali. The purpose of this study was to determine the performance of prospective Bali bull, to determine the magnitude of breeding value and to obtain candidates for superior bull based on the chest girth of each prospective bull on Nusa Penida Island.

\section{MATERIALS AND METHODS}

The study was carried out in five villages (Ped, Suana, Pejukutan, Batumadeg and Batukandik) on Nusa Penida Island. The study was carried out by measuring of chest girth of 194 male Bali cattle, consisting of 147, 28 and 19 heads that have $\mathrm{I} 0, \mathrm{I} 1$ and $\mathrm{I} 2$ respectively.

The purposive random sampling technique is used in this research. The data were analyzed descriptively. Performance is measured by calculating the average chest girth with the formula: $\bar{X}=\frac{\sum x}{n}$, where $\bar{X}=$ mean; $\sum x=$ the total value and $n$ is the number of livestock measured

Estimation of breeding value is calculated using individual selection methods (performance test) with the formula $\mathbf{N P}=\mathbf{h}^{2}(\mathbf{P i}-\overline{\mathbf{P}})$ where $\mathrm{NP}=$ the breeding value; $\mathrm{h}^{2}=$ heritability; $\mathrm{Pi}=$ individual chest girth and $\overline{\mathrm{P}}=$ population average of chest girth. Heritability value of chest girth used in this calculation refers to the results of research by Supriyantono, et al. that is equal to 0.50 [6]. Estimation of breeding value is calculated after selecting as many as $5 \%$ of the total male at each age. Then, male were ranked based on the calculation of the average chest girth and estimation of breeding values [6].

\section{RESULTS AND ANALYSIS}

\section{Average of Chest Girth}

The average chest girth of male Bali cattle based on age groups (I0, I1 and I2) were $135.65 \pm 16.98 \mathrm{~kg} ; 159.57 \pm 13.75 \mathrm{~kg}$ and $166.26 \pm 19.94 \mathrm{~kg}$ respectively (Table $1)$.

Table 1. The Average Chest Girth of Male Bali Cattle Based on Their Age Groups (I0, I1 and I2) in Nusa Penida Island

\begin{tabular}{lccccccc}
\hline Variable & \multicolumn{7}{c}{ Age groups } \\
\cline { 2 - 8 } & \multicolumn{2}{c}{$\mathrm{I} 0$} & $\mathrm{n}$ & $\mathrm{X}$ & $\mathrm{n}$ & $\mathrm{X}$ \\
\cline { 2 - 7 } & $\mathrm{n}$ & $\mathrm{X}$ & $\mathrm{n}$ & 159,57 & 19 & 166,26 \\
CG $(\mathrm{cm})$ & 147 & 135,65 & 28 & $\pm 13,75$ & & $\pm 19,94$ \\
& & $\pm 16,98$ & &
\end{tabular}

Noted:

$\mathrm{CG}=$ Chest girth $(\mathrm{cm}) ; \mathrm{n}=$ number (head); $\mathrm{X}=$ Average $\pm=$ Standard deviation

The average chest girth of male Bali cattle with I1 was higher than the quantitative minimum requirements for chest girth of prospective Bali bull class I at age of 18-24 months (I1) based on Indonesian National Standard (SNI) 7651.4: 2015 , which requires $155 \mathrm{~cm}$. This proves that male Bali cattle on Nusa Penida Island are prospective as a bull who can be used as superior bull for matting of dam Bali cattle so that the genetic quality of Bali cattle will increase.

The average chest girth of male Bali cattle with I 2 was $166.26 \pm 19.94 \mathrm{~cm}$. The 
result is lower than the quantitative minimum requirements for male grade I of Bali cattle chest girth for ages $>24-36$ (I2) that is equal to $179 \mathrm{~cm}$, but it is higher than the quantitative minimum requirements for chest girth of Bali cattle grade II for age> 24- 36 (I2) that is equal to $158 \mathrm{~cm}$. This is likely due to the small amount of data caused by the lack of male in the age composition in the community. In general, farmers will sell male Bali cattle at the age of I1 if they are not used as a breeding stock. This can be seen as a fact that there are fewer male Bali cattle aged group of I1 and $\mathrm{I} 2$ in the community compared to those in the age group of $\mathrm{I} 0$.

The Chest girth in the age composition of I0 cannot be compared with SNI 7651.4: 2015, because the chest girth of the age composition of I0 is not listed in the minimum requirements of male Bali cattle chest girth on SNI 7651.4: 2015. This is likely because the appearance of individuals in the age composition of I0 cannot be used as a reference selection. The influence of their parents are still visible in individuals with an age composition of I0. While at the age group of I1 and I2, they can meet their own nutritional needs and can adapt to their own environment without the influence of their parent. The greater of the chest girth, the better and faster of animal's growth because the chest girth has a very close relationship to body weight. This statement is in accordance with the results obtained by Tama, et al and Warmadewi, et al [2][3].

Based on the average of chest girth, then male Bali cattle with the code of BK030 in the age composition of I1 and male Bali cattle with the code of BK101 in the age composition of I2 occupyy the highest rank with the average chest girth of $182 \mathrm{~cm}$ and $210 \mathrm{~cm}$ respectively. In the selection program, these two male Bali cattle can be used as candidates for superior bull.

\section{Breeding Value Estimation of Chest Girth}

The analysis of estimated breeding value of chest girth in the age group of I0, I1, I 2 on Nusa Penida Island are presented in Tables 2, 3 and 4.

Based on the calculation of the estimated breeding value of chest girth at the age group of $\mathrm{I} 0$, it was found that the prospective bali bull coded PD020 occupies the highest rank with breeding value of $24.18 \mathrm{~cm}$. This means that if Bali bull candidate is mated with the dams randomly in the normal population, then the average hereditary performance will show a $12.9 \mathrm{~cm}$ superiority to the population performance. This is in accordance with Hardjosubroto's statement which states that if the bull which has been known its breeding value is mated with the dams randomly in the normal population, then the average performance of the breeds will show their superiority of a half of the bull breeding value to the performance their population [1]. 
TABLE 2. BREEDING VALUE ESTIMATION OF CHEST GIRTH IN THE AGE GROUP OF I0

\begin{tabular}{clll}
\hline No. & Code & CG $(\mathrm{cm})$ & BV $(\mathrm{cm})$ \\
\hline 1. & PD020 & 184 & $24,18^{(1)}$ \\
2. & BK062 & 179 & $21,68^{(2)}$ \\
3. & BK061 & 176 & $20,18^{(3)}$ \\
4. & PD140 & 167 & $15,68^{(4)}$ \\
5. & BK330 & 165 & $14,68^{(5)}$ \\
6. & PD010 & 165 & $14,68^{(5)}$ \\
7. & BM160 & 165 & $14,68^{(5)}$ \\
8. & BK070 & 164 & $14,18^{(6)}$ \\
\hline
\end{tabular}

Noted:

$\mathrm{CG}=$ Chest girth $(\mathrm{cm}) ; \mathrm{BV}=$ Breeding Value; ()$=$ the small superscript behind the number indicates the livestock rank

TABLE 3. BREEDING VALUE ESTIMATION OF CHEST GIRTH IN THE AGE GROUP OF I1

\begin{tabular}{llcc}
\hline No. & Code & CG $(\mathrm{cm})$ & BV $(\mathrm{cm})$ \\
\hline 1. & BK030 & 182 & $11,21^{(1)}$ \\
2. & SU070 & 182 & $11,21^{(1)}$ \\
\hline
\end{tabular}

Noted:

$\mathrm{CG}=$ Chest girth $(\mathrm{cm}) ; \mathrm{BV}=$ Breeding Value; ()$=$ The small superscript behind the number indicates the livestock rank

TABLE 4. BREEDING VALUE ESTIMATION OF CHEST GIRTH IN THE AGE GROUP OF I2

\begin{tabular}{llll}
\hline No. & Code & CG $(\mathrm{cm})$ & BV $(\mathrm{cm})$ \\
\hline 1. & BK101 & 210 & $21,87^{(1)}$ \\
\hline
\end{tabular}

Noted:

$\mathrm{CG}=$ Chest girth $(\mathrm{cm}) ; \mathrm{BV}=$ Breeding Value; ()$=$ the small superscript behind the number indicates the livestock rank

The higher the breeding value, the more superior the characteristics of the animal and the offspring. This was confirmed by Dakhlan and Sulastri who stated that individuals with high breeding values would show their ability to inherit their genetic potential to their offspring and the potential appearance of parents would appear in their offspring [7]. This opinion is also in line with research conducted by Sumeidiana, et al., males who have the best breeding values can be selected as superior bulls to mate superior dams, so that their offspring are expected to have good production such as their parents, while bulls and dams who have low genetic potential can be culled because it is assumed when they were used for mating, their offspring will have low productivity such as their parents [8].

The magnitude of the breeding value is also very much determined by the magnitude of the heritability value used in the calculation. Heritability greatly influences the breeding value, because heritability is a genetic parameter that is used as a basis for calculating breeding values. The amount of heritability is influenced by the magnitude of genetic variation. This is consistent with the opinion of Warmadewi which states that the higher the genetic variation, the higher the heritability value [9]. Conversely, if 
environmental variation is higher, the heritability value will be lower. The heritability value of 0.50 which is used in this study means that $50 \%$ of genetic variation in the population is influenced by genetic factors, and $50 \%$ is influenced by environmental factors.

At the age composition of I1, which occupies the highest rank with breeding value of $11.21 \mathrm{~cm}$ is a candidate for Bali bull with the code of BK030. The highest ranking for the age composition of $\mathrm{I} 2$, is occupied by prospective Bali bull coded BK101 with breeding values of $21.87 \mathrm{~cm}$.

Estimation of breeding values obtained in this study can be used as a basis for selection in selecting a superior Bali bull candidate. This statement is in accordance with the opinion of Bourdon (1997) if the breeding value of each livestock is known with certainty, then determining the rank of superiority of livestock in the population can be known easily [10].

The magnitude of the breeding value in the age composition of I0 cannot be used as a reference in the selection program because the livestocks performance in this age composition has not shown their individual ability. On the other hand, livestock in the age composition of I1 and I 2 can be used as a reference in the selection program because the livestock performance is the ability of the livestock itself and the interaction with the environment.

Based on the breeding value of chest girth, Bali cattle coded BK030 and BK101 occupy the highest rank so that it can be used as a superior Bali bull candidate. If this bull is mated with Bali dams, it is expected to be able to improve the genetic quality of Bali cattle.

\section{CONCLUSION}

Bali cattle coded BK030 with I1 and the one coded BK101 with I2 were on highest rank position, so that it can be selected as a candidate for superior Bali bull. When these cattles are mated with Bali heifers/dams, it is expected that the genetic quality of their offspring will increase.

\section{ACKNOWLEDGEMENT}

We would like to express our gratitude to the Regional Government of Klungkung Regency, Bali Province for providing research facilities. Furthermore, we appreciate not only the Rector of Udayana University for the research funding in the scheme of the Udayana excellent Program so-called "Program Unggulan Udayana-PUU" but also the Dean of the Faculty of Animal Husbandry for the permission given to conduct research.

\section{REFERENCE}

[1] Hardjosubroto, W. 1994. Aplikasi Pemuliabiakan Ternak di Lapangan. Penerbit PT Grasindo. Jakarta

[2] Tama, W.A., M. Nasich dan S. Wahyuningsih. 2016. Hubungan antara lingkar dada, panjang dan tinggi badan dengan bobot badan kambing Senduro jantan di Kecamatan Senduro, Kabupaten Lumajang. Jurnal Ilmu-Ilmu Peternakan 26 (1): $37 \quad-42$. Fakultas Peternakan UB, http://jiip.ub.ac.id/

[3] Warmadewi, D.A., I G. L. Oka, dan I N. Ardika 2017. Efektivitas seleksi dimensi tubuh sapi bali induk. Majalah Ilmiah Peternakan. Volume 20. No. 1. Peb 2017

[4] Warmadewi, D.A., IGNG Bidura dan IN Budiana. 2017. Comparison of estimated genetic improvement of bali cattle based on the selection of body dimension. Journal of Veterinary and Animal Science. Vol. 1 No. 2:59-61. September 2017 
[5] Johanson, I and J. Rendel. 1969. Genetic and Animal Breeding. San Fransisco

[6] Supriyantono, A., L. Hakim, Suyadi and Ismudiono. 2012. Genetic Improvement of Weaning Weight, Yearling Weight, Body Weight Gain And Body Dimension of Bali Cattle 2012. J.Indonesian Trop.Anim.Agric. 37(1) March 2012

[7] Dakhlan, A. dan Sulastri. 2002. Ilmu Pemuliaan Ternak. Buku Ajar. Jurusan Produksi Ternak, Fakultas Pertanian. Universitas Lampung. Bandar Lampung.
[8] Sumeidiana. I.K, E. Kurnianto dan A.T.Hantoro. 2015. Pendugaan nilai pejantan sapi perah di BBTU sapi perah baturraden. Fakultas Peternakan dan Pertanian, Universitas Diponegoro. Agromedia. Vol 33 (2): 55-64

[9] Warmadewi, D.A. 2014. Respons Sapi Bali terhadap Pelaksanaan Seleksi dan Aplikasi Inseminasi Buatan di BPTU Sapi Bali. Disertasi Program Pasca Sarjana Universitas Udayana. Denpasar

[10] Bourdon, R.M. 1997. Understanding Animal Breeding. Prentice Hall, Inc. New Jersey 